\title{
Conservation of grassland butterflies in Finland under a changing climate
}

\author{
Anna Tainio - Risto K. Heikkinen • Janne Heliölä • Alistair Hunt • \\ Paul Watkiss · Stefan Fronzek · Niko Leikola • Sanna Lötjönen · \\ Olga Mashkina $\cdot$ Timothy R. Carter
}

Received: 25 October 2013/Accepted: 11 August 2014/Published online: 10 September 2014

(C) The Author(s) 2014. This article is published with open access at Springerlink.com

\begin{abstract}
This paper examines the potential impact of climate change on grassland butterfly species in Finland. It combines multiple climate change scenarios and different impact models for bioclimatic suitability to capture multifaceted aspects of uncertainty. It also evaluates alternative options to enhance the adaptation of grassland biodiversity. Due to the long-term decline of semi-natural grasslands, their current extent in Finland is much lower than the minimum level estimated to ensure the survival of butterfly species. Projected locations of the climatically most suitable areas for butterfly species varied considerably between different modelling techniques and climate change
\end{abstract}

Electronic supplementary material The online version of this article (doi:10.1007/s10113-014-0684-y) contains supplementary material, which is available to authorized users.

\author{
A. Tainio $\cdot$ O. Mashkina \\ Environmental Policy Centre, \\ Finnish Environment Institute (SYKE), Box 140, \\ 00251 Helsinki, Finland \\ e-mail: anna.tainio@alumni.helsinki.fi \\ O. Mashkina \\ e-mail: olga.mashkina@gmail.com \\ R. K. Heikkinen · J. Heliölä · N. Leikola \\ Natural Environment Centre, Finnish Environment Institute \\ (SYKE), Box 140, 00251 Helsinki, Finland \\ e-mail: risto.heikkinen@ymparisto.fi \\ J. Heliölä \\ e-mail: janne.heliola@ymparisto.fi \\ N. Leikola \\ e-mail: niko.leikola@ymparisto.fi \\ A. Hunt \\ Department of Economics, University of Bath, \\ Claverton Down, Bath BA2 7AY, UK \\ e-mail: a.s.p.hunt@bath.ac.uk
}

scenarios. This uncertainty needs to be taken into account in planning adaptation responses. Analysis of potential adaptation options considered the promotion of existing measures based on the agri-environmental scheme (AES), as well as new measures, including species translocation and dispersal corridors. Current AES options were compared using a cost-effectiveness analysis (CEA). The CEA results indicated that buffer zones are the most costeffective AES measure, although environmental fallows and buffer zones had broadly similar cost-effectiveness. The cost of translocation was relatively modest compared to that of dispersal corridors, due to the high number of habitat stepping stones required along potential dispersal corridors. A questionnaire survey of Finnish farmers revealed that a third of the respondents supported increases

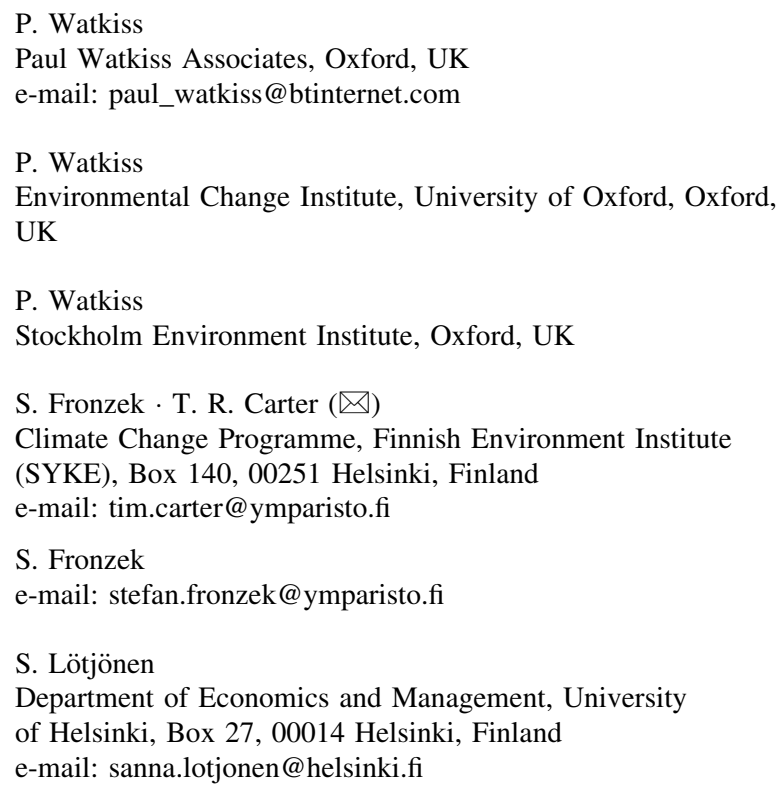


in nature conservation. Thus, large increases of the uptake of biodiversity-related AES measures among farmers may prove to be difficult. Given the small areas currently assigned for such measures, the prospects for the adaptation of grassland butterflies to climate change in Finland appear unfavourable.

Keywords Adaptation - Agri-environmental scheme (AES) - Ecological corridor - Species translocation . Bioclimatic envelope modelling · Cost-effectiveness analysis

\section{Introduction}

Traditionally managed semi-natural grasslands are one of the most species-rich habitats in Europe, and their preservation is crucial for the protection of biodiversity (Pykälä 2000; Kivinen et al. 2008; Kleijn et al. 2011). However, the maintenance of semi-natural grasslands and their biota is threatened due to their drastic decline caused by changes in agricultural practices (Wenzel et al. 2006; Polus et al. 2007). There are two main trends which are especially harmful to farmland biodiversity and can decrease species dispersal and persistence possibilities: increasing conversion of seminatural grasslands for cultivation or other use, and abandonment of traditionally managed farmland habitats leading to overgrowth (Strijker 2005; Öckinger et al. 2006).

Climate change will pose additional challenges for the grassland species (Warren et al. 2001; Wallisdevries and Van Swaay 2006), especially in high-latitude environments where changes in climate are projected to be largest (Loarie et al. 2009) and where species are expected to shift their ranges polewards (Peterson et al. 2004; Virkkala et al. 2008). For some endangered species, management strategies may be available for creating cooler microclimates in grasslands at existing locations, to offset some of the warming effects and allow additional time for local genotypes to adapt to changed conditions (Settele and Kühn 2009). However, for most species, the success of range shifts depends on the ability of species to move to new areas. This is a function of their dispersal ability, the availability of suitable habitats in the landscape and human-related factors affecting land use and conservation (Warren et al. 2001; Hannah et al. 2007; Huntley et al. 2010). Failure to track the improving climate at high-latitude margins, combined with shrinking distributions due to overly high temperatures at low-latitude margins (Franco et al. 2006), will result in overall negative impacts on grassland butterflies.

This paper investigates the potential impacts of climate change on semi-natural grassland biodiversity in Finland and considers potential adaptation options, looking at these changes in the context of the current network of managed grassland sites. The study focuses on a key indicator species, grassland butterflies, investigating the potential distributional shifts of these species under a changing climate through the existing network of grassland sites and assessing whether new or increased managed grassland areas are needed to ensure the success of butterfly dispersal in Finland. Butterflies were considered suitable for representing broader grassland biodiversity because their distributional information is abundant in many regions, they are likely to respond rapidly to climate change (Menéndez 2007; Pöyry et al. 2009), and they have proven to be useful indicators of the conservational status and recreational value of grasslands (Van Swaay et al. 2010; Bastian 2013; van Berkel and Verburg, in press). A number of adaptation measures are examined here: existing conservation measures included in the agri-environmental scheme (AES) and two new measures-dispersal corridors and species translocation. Estimates of their potential cost-effectiveness are given, and the attitudes of farmers to these measures, in particular, and more generally to conservation of biodiversity in agricultural areas are also considered.

The work reported here is one of a number of case studies on climate change adaptation conducted within a common "diagnostic framework for adaptation research" (Hinkel and Bisaro 2014) developed in the MEDIATION (Methodology for Effective Decision-making on Impacts and AdaptaTION) project of the European Commission's Seventh Framework Programme. This is an iterative framework comprising a number of stages of assessment typically applied in research to support practical adaptation (Fig. 1). Stage 1 is a general review phase, looking at the background context and available data, as well as defining the climate change adaptation problem. This contextual information was already presented above, while data aspects are treated in the following sections. Stages 2 and 3 incorporate the four main analytical steps of the study, with methods detailed in the "Materials and methods" section and results reported in the "Analysis and results" section of the paper. Finally, Stage 4 of the study, synthesizing the main conclusions and implications of the results for Finnish conservation planning, is presented in the "Conclusions" section. Some of the detailed methods and analyses are presented in Supplementary Material (SM).

\section{Materials and methods}

The main analytical methods adopted in the study are organized according to the four steps shown in Fig. 1: impact analysis, socio-institutional and policy setting, costeffectiveness of adaptation options and farmers' perspectives. Some steps required the application of multiple methods. 


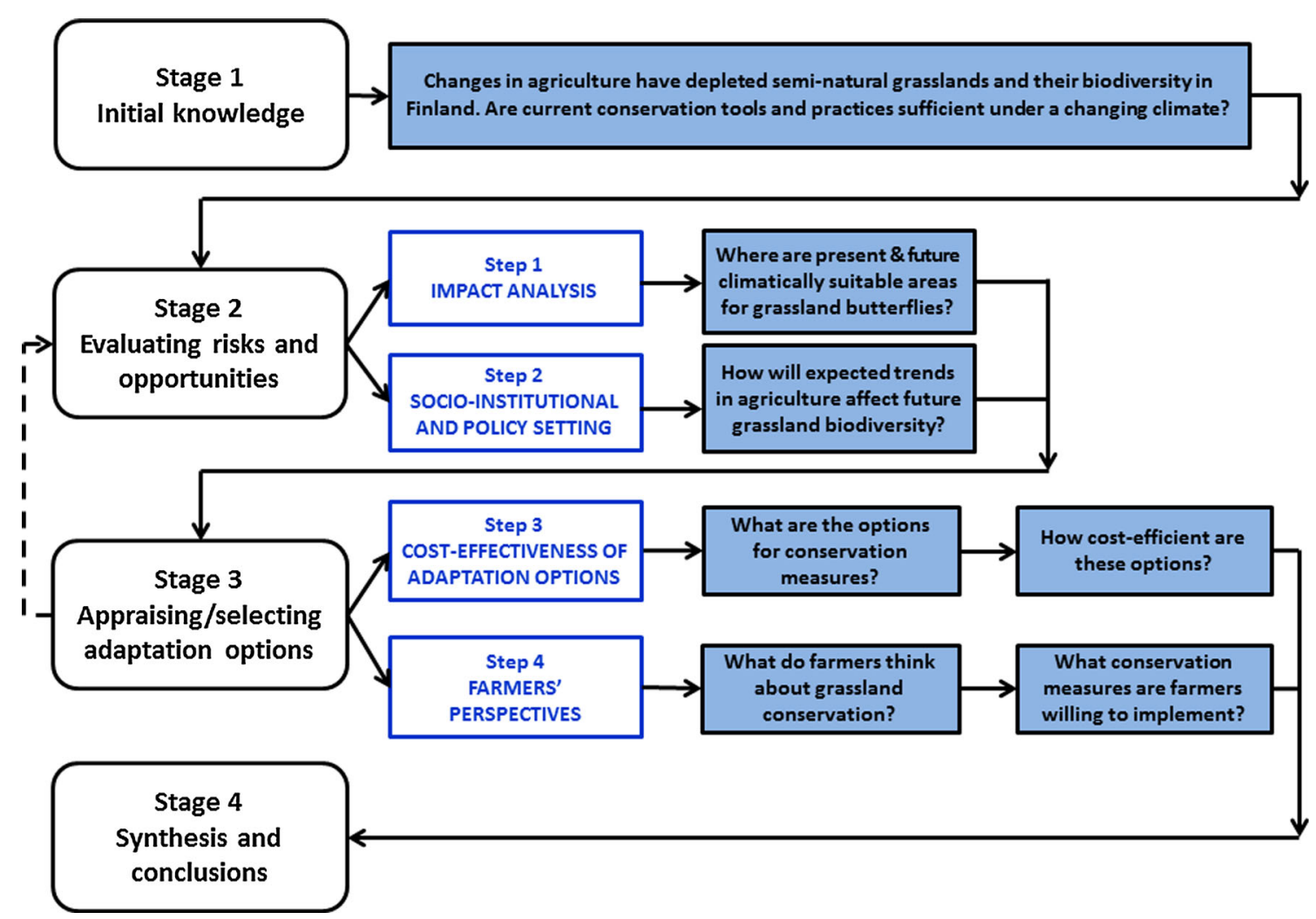

Fig. 1 Methodological pathway followed to analyse climate change adaptation strategies for biodiversity conservation in south-western Finland

Step 1: impact analysis

\section{Climate change scenarios}

Projections of future climate over Finland were represented using five climate change scenarios that were chosen to span a range of future climates described by ensembles of general circulation model simulations. These assumed a range of future emissions of greenhouse gases and aerosols affecting the global climate (SM, section S1.2). The scenarios were labelled with a number followed by three characters- $\mathrm{L}$ for low, $\mathrm{M}$ for medium or $\mathrm{H}$ for high, indicating their relative position in terms of: (1) strength of their emission scenario, (2) annual mean temperature change and (3) annual precipitation change (Table S1.2, SM). The climate change scenarios were applied to climatological observations on a $10 \mathrm{~km} \times 10 \mathrm{~km}$ grid over Finland for the period 2051-2080.

\section{Impact models}

The potential impacts of future climate change on grassland butterfly species were assessed using bioclimatic envelope models (BEMs). Such models correlate current species distributions with climate variables and then forecast spatial shifts in climatically suitable areas under projections of climate change (e.g. Heikkinen et al. 2006; Lawler et al. 2006). When applied with caution, BEMs provide useful "first filters" for determining approximations for the directions of species range shifts (Araújo and Peterson 2012).

Bioclimatic envelopes for butterflies were determined by relating species distributions in Europe to four climate variables (Hill et al. 2003; Heikkinen et al. 2010): mean temperature of the coldest month (MTCO), annual daily temperature sum above $5{ }^{\circ} \mathrm{C}$ (growing degree days, GDD5), annual water deficit (WD) and mean annual precipitation (PREC). These were computed first using observed climate data for Europe averaged for the period 1971-2000 (SM, section S1.1). Future suitability was then projected using the five climate change scenarios generated for Finland for the period 2051-2080 ("Climate change scenarios" section).

The BEMs were developed using the BIOMOD user interface, as implemented in the $\mathrm{R}$ statistical package (Thuiller et al. 2009), using three robust modelling methods (Heikkinen et al. 2012): generalized additive models (GAM), generalized linear models (GLM) and generalized boosting methods (GBM). Overall, the combination of 
three types of BEMs and five climate projections leads to 15 different projections of the distribution of future suitable areas in Finland for each of the modelled species.

A set of 27 butterfly species was employed in the study, which passed two main criteria: (1) the accuracy of the pilot BEMs generated for the species was sufficient, as measured with cross-validation tests based on the 70:30 split-sample approach and associated AUC and TSS statistics for model accuracy (Fielding and Bell 1997; Allouche et al. 2006; SM, section S2.2); (2) a species should already occur in Finland at present in order to be selected. The second criterion was adopted to align with the focus on existing Finnish AES and because subsequent options for dispersal corridors and species translocations (see "Step 3: cost-effectiveness of adaptation options" section) are difficult to plan and realize across state boundaries.

\section{Suitability mapping and corridor analysis}

An analysis using geographic information system (GIS) techniques was employed to measure the cover of different grassland habitats at butterfly monitoring sites where certain grassland butterfly species have had persistent populations. This provided a comparison point for the target level of grassland habitat required to sustain a viable population. Next the difference between the target level and actual grassland cover was computed for a small number of areas estimated to be climatically highly suitable for butterflies in the future. This analysis was conducted using the $10-\mathrm{km}$ resolution grid.

Similar grassland cover calculations were also performed for the potential dispersal routes (corridors) between present-day locations of an exemplar butterfly species, Hesperia comma, and six illustrative areas projected to be highly suitable in the future for the species under a given combination of BEM method and climate scenario. These calculations were undertaken at a $2 \mathrm{~km} \times 2 \mathrm{~km}$ grid resolution, as the $10-\mathrm{km}$ grid would have been too coarse for establishing dispersal possibilities.

Taken together, these assessments provided information on where grassland butterflies are likely to face difficulties in population persistence or dispersal and where new conservation or other adaptation actions might be required to support grassland biodiversity. It should be noted that the effects of climate change on grassland vegetation were not assessed as part of the study, i.e. the analysis investigates the effects of climate change on butterfly species, but not on the composition or success of vascular plant species inhabiting grasslands. Previous European studies (Tietjen et al. 2011) have suggested that plant species of grasslands have generally higher tolerance levels than butterfly species to climate change, i.e. impacts are likely to relate to changes in productivity rather than survivability. However, although many of the host plants for grassland butterfly larvae exhibit a wide geographic range, which is not limiting for species range expansion, others may either shift their ranges more slowly or in a different direction than the butterflies that depend on them (Schweiger et al. 2012). In such cases, a successful introduction of a butterfly species into a new area can be difficult but may happen via one of two "adaptive pathways": species-based behavioural adaptation, to exploit a wider range of larval host plants (Braschler and Hill 2007), or human-based adaptation via translocation of the required host plants to the future suitable areas. In addition, climate change may act with other environmental changes (such as increased nitrogen deposition) to enhance the spring flush, possibly favouring dominance of rapidly growing weed species, which in turn cool the microclimate to the detriment of butterflies favouring warmer, shorter swards (Wallisdevries and Van Swaay 2006). Here, management responses such as increased grazing intensity or altered rotations may be required.

Step 2: socio-institutional and policy setting

The quantitative impact assessment in Step 1 was complemented in Step 2 with a socio-institutional literature review. The latter focused on grassland conservation and policy issues, as well as the structure of Finnish agriculture and possible future changes, noting these will affect the potential for adaptation. Farmers are the most important group of actors for maintaining semi-natural grasslands in Finland (Kemppainen and Lehtomaa 2009). Finnish agriculture is struggling with tight profit margins, and profitability seems to be the primary driver of biodiversity loss in grassland habitats. Even though many farmers undoubtedly appreciate their cultural history, heritage and protection of nature in general (see "Step 4: farmer survey" section), in most cases, such sentiments are not sufficient grounds to motivate them to maintain traditional landscapes and habitats at their own expense. The need for public funding to maintain valuable grasslands has been repeatedly recognized as a priority in several governmental evaluations and assessments since the 1990s. The willingness of farmers to take up conservation actions is clearly influenced by the financial support provided by the agri-environmental scheme (AES) for managing semi-natural grasslands and other valuable habitats. The AES system therefore forms the focus of the review.

Step 3: cost-effectiveness of adaptation options

Step 3 is concerned first, with the identification of alternative adaptation measures and second, with 
appraising these options in order to determine possible priorities. For unmanaged or semi-managed ecosystems, there is a range of potential measures for adapting to climate change, many of which build on addressing existing risks or extending existing conservation. For this study, the initial focus was on current options already employed in Finland, notably the existing agri-environmental scheme (AES). However, it was judged that the AES may not be a sufficient measure enabling species to cope with future climate change. Therefore, additional options of species translocation (Willis et al. 2009) and dispersal corridors were also considered. Data on the effectiveness of the current AES scheme were identified and analysed, along with analysis of the potential effectiveness of these new options, based on pilot studies and wider literature.

The appraisal of alternative adaptation measures required a decision support method. For the analysis of AES, cost-effectiveness analysis (CEA) was used (Watkiss and Hunt 2012). CEA is a widely used quantitative decision support tool which compares alternative options for achieving similar outputs or objectives (Pearce et al. 2006; Zhu and van Ierland 2010). At the technical or project level, CEA can be used to compare and rank alternative options by assessing options in terms of the cost per unit of benefit delivered. This identifies those options that deliver highest benefit for lowest cost, i.e. the most cost-effective. The analysis combines the effectiveness of options with information on the establishment and management costs of different adaptation measures, in order to provide a ranking of cost-effectiveness. In the context of this paper, where multiple climate scenarios and impact models are used, the application of CEA can also be extended to capture uncertainty.

\section{Step 4: farmers' perspectives}

In order to analyse farmers' views about grassland biodiversity conservation, a stakeholder workshop was held in August 2011 and an extensive questionnaire survey sent to a random sample of 2,000 farmers in two adjacent regions-South-west Finland and Pirkanmaa-in April 2012. The aim of the workshop was to identify adaptation options that were supported by the farming community, as the main implementing actors for grassland conversation. The information from the workshop was used to develop the survey, which was designed to collect farmers' views on the status of wildlife and biodiversity on their farmlands, on how climate change affects both farm management and conservation efforts, and on the types of interventions they considered most appropriate or acceptable for enhancing the resilience of species and habitats to climate change.

\section{Analysis and results}

Step 1: projections of future climatic suitability for butterflies

Projections using three different calibrated BEMs under five climate change scenarios show clear spatial differences in the projected locations of the climatically most suitable areas for different butterfly species, though some areas overlap. An illustration comparing four species is provided in SM, section S3. However, there are also several sources of uncertainty in projections of suitability. Figure 2 explores two of these, showing a comparison of the impacts of alternative climate change scenarios and of different modelling methods for one butterfly species (Parnassius mnemosyne). Three BEM techniques can be compared for the same climate change scenario (1MMH-see Table S2, $\mathrm{SM}$ ) in panels $\mathrm{A}, \mathrm{B}$ and $\mathrm{C}$, and show large differences in projected suitability. Similarly, there are even greater differences in suitability across five climate change scenarios applied to a single modelling technique (GAM) when comparing panels A, D, E, F and G.

Figure 2 emphasizes the large uncertainties involved in projecting future species suitability, presenting potential challenges for adaptation planning. On the other hand, a focus on those areas where model projections agree across scenarios and models, such as in panels A, C, D and E, could offer valuable information for designing adaptation strategies that are more robust under uncertainty.

For one example species, Hesperia comma, the BEM results were analysed in detail and employed to investigate two hypothetical adaptation responses: (1) the construction of dispersal corridors between present-day species populations and future suitable areas, and (2) translocations, involving the capture, transport and release of species into future suitable sites (the corridor endpoints). For this particular species, the analysis identified thirty $10-\mathrm{km}$ grid cells that showed the highest climatic suitability under the climatic conditions of 2051-2080 and which already contain grasslands. To provide an illustration of the impacts of varying the modelling method and climate change scenario, this process was repeated for three scenarios (2LLL, $1 \mathrm{MMH}$ and $4 \mathrm{HMM}$ ) and two modelling methods (GAM and GLM). The results show that there are clear spatial differences between the locations of the thirty future climatically most suitable grid cells, including the ten most suitable cells in the results based on different models or scenarios (Fig. 3).

Step 2: the policy environment for adaptation measures

In 2006, the agri-environmental schemes (AES) implemented by farmers covered an area of about 24,500 
Fig. 2 Projected suitability (low to high) for the Parnassius mnemosyne butterfly in 2051-2080 assuming three bioclimatic envelope modelling methods (GAM, GLM, GBM) and five climate change scenarios (Table S1.2, SM) combined as follows: a GAM, $1 \mathrm{MMH}$; b GBM, 1MMH; c GLM, 1MMH; d GAM, 2LLL; e GAM, 3LLL; f GAM, 4HMM; and $\mathbf{g}$ GAM, 5HHH. Increasing red colouration indicates higher projected climatic suitability

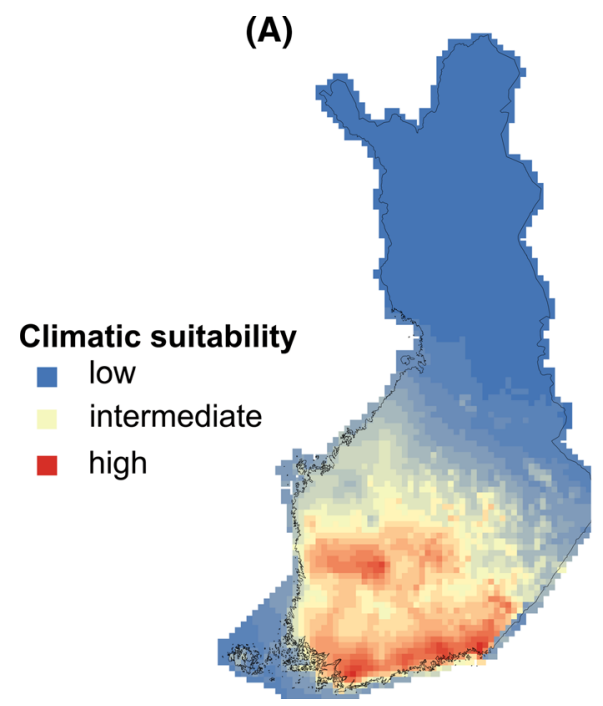

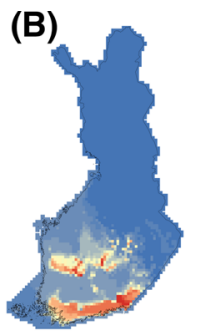

(E)

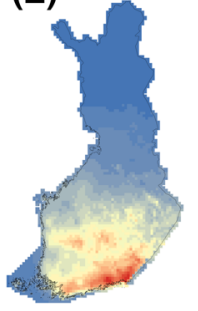

(C)

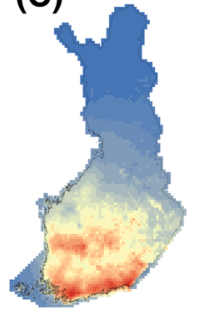

(F)

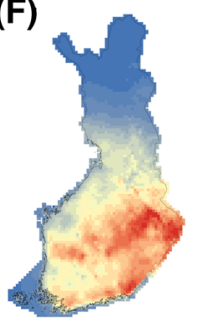

(D)

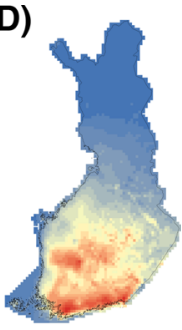

(G)

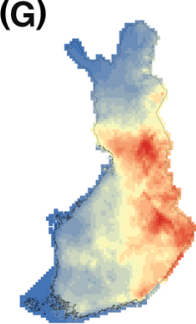

(A)

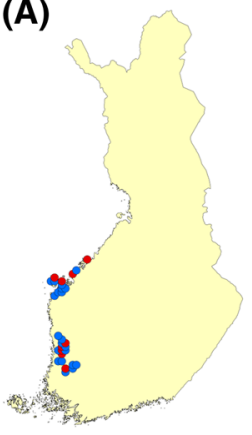

(D)

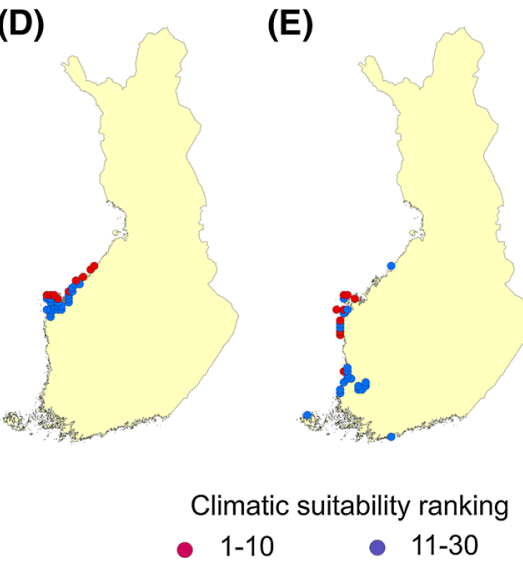

Fig. 3 Location of the thirty $10-\mathrm{km}$ grid cells projected to be climatically most suitable in 2051-2080 for the Hesperia comma butterfly. Key to bioclimatic envelope models and climate change scenarios: a GAM, 2LLL; b GAM, 1MMH; c GAM, 4HMM; d GLM, 2LLL; e GLM, 1MMH; and f GLM, 4HMM. The ten most suitable cells are shown in red; the remaining 20 cells (11-30) in blue

hectares, which is almost ten times more than the area managed by all other landowners combined. Metsähallitus, the public enterprise that manages state-owned land and water areas, is second in importance, managing ca. 2,700 ha of semi-natural habitats annually. A number of
NGOs, such as the Finnish Association for Nature Conservation and the World Wildlife Fund (WWF), have an additional, minor role in grassland conservation.

The utilized agricultural area (UAA) in Finland is ca. 2.3 million ha, representing about $8 \%$ of the total land area (TIKE 2011). Natural meadows and pastures constitute approximately $1 \%$ of the UAA. Public funding for the management of semi-natural grasslands comes almost exclusively from the national AES directed to farmers, with some additional funding from the regional authorities directed to local-level NGOs. Although there has been sufficient funding for biodiversity-related AES measures in recent years, their uptake has been rather low, slowing down but not reversing the decline of traditional rural biotopes. This has been attributed to low payment levels and high transaction costs (Schulman et al. 2006).

The future agricultural policy landscape over the period of analysis here (to 2080) is difficult to anticipate. Pyykkönen et al. (2010) have presented forecasts of structural changes in Finnish agriculture from 2010 to 2020, which is particularly relevant in the context of short-term adaptation responses. According to their estimates, the continuing decline seen over recent decades in the number of livestock farms is expected to increase by an additional $50 \%$ by 2020 . The largest decreases are projected for dairy farms, which are currently responsible for maintaining most of the semi-natural grasslands. The projected increases in other livestock are unlikely to compensate these losses due to their relatively small extent. There is also an ongoing drive to increase livestock units per farm, which is likely to increase pressures to abandon the less productive semi-natural grasslands and replace them with cultivated pastures. These underlying socio-economic trends are likely to exacerbate the effects of climate change, through the loss of suitable future sites and poorer connectivity. However, it is possible that currently 
unforeseeable changes could arise in either EU- or Finnish agri-environmental policies, which would provide greater incentives for semi-natural grassland management through AES or some other funding mechanism.

\section{Step 3: identification and appraisal of options}

Following the identification of future risks, potential adaptation options to enhance the resilience of grassland butterflies to climate change were identified and appraised. An important element was to compare alternative options in terms of their relative effectiveness and their efficiency (costs), as measured through a CEA. However, it was also necessary to assess whether these options were sufficient to ensure the survival of grassland species, recognizing that thresholds to ecosystem viability might be exceeded as the limits to adaptation for these natural ecosystems are approached.

On the basis of an initial literature review and scoping analysis, three different types of adaptation options were identified: (1) AES measures, (2) dispersal corridors and (3) species translocations. It should be noted that the first two options have inter-linkages, because constructing dispersal corridors for species dispersal would be likely to use AES measures along the planned corridor areas. Species translocation is a quite different alternative.

\section{Determining the area of grassland to support viable populations}

The CEA in this paper is based on analysis of the most cost-effective way to achieve pre-defined target levels, in this case a scientific target level for the amount of grassland habitat required to support viable grassland butterfly species populations. This is an absolute target resilience level for ecosystem sustainability and follows from a high-level policy goal to preserve these grassland ecosystems (Salminen and Kekäläinen 2000). The analysis of the viability threshold for the CEA was based on existing survey analysis, with analysis in a GIS database. This mapped three types of grassland habitats at a resolution of $25 \mathrm{~m} \times 25 \mathrm{~m}$ in Finland:

1. grasslands managed with funding from the AES (Arponen et al. 2013);

2. grasslands identified as valuable for agro-biodiversity in a previous nation-wide survey (Vainio et al. 2001), but which currently do not have an AES contract; and

3. common grasslands that are of low or moderate value for agro-biodiversity (Kuussaari et al. 2007).

The grassland cover information was integrated with data from more than 170 butterfly monitoring transects.
The data from the 30 transect areas with most abundant grasslands and records of one or more grassland specialist butterfly species (usually over a number of years) were analysed separately, and the median of the summed cover of the three grassland types in the 2-km grid cells with the species transects was calculated. The results suggested that ca. $2.5 \%$ of the landscape should be covered by grassland habitats to support viable grassland butterfly populations. A viable population was broadly defined here as a local population of a given species which had persisted over several years, based on transect monitoring data or local butterfly recorders' knowledge. Many of the chosen transects have been established on sites known a priori to have important grasslands or to have historical records of demanding grassland species. The analysis of each of the three main adaptation options is presented in the following sections.

\section{AES measures}

AES measures are currently the main tool for conservation of grassland biodiversity in Finland, implemented through the use of financial incentives (payments) to farmers. A detailed description of the Finnish AES measures can be found in MAF (2007). Based on the earlier expert evaluation by Grönroos et al. (2007), we selected those AES measures which were known to have at least some significance for butterflies, i.e. that the area where the measure takes place can serve as habitat for some of the more common grassland butterfly species. The potential AES options included one obligatory basic measure: buffer strips of $>3 \mathrm{~m}$ along waterways, and three voluntary special measures: management of traditional biotopes, buffer zones of $>15 \mathrm{~m}$ along waterways and environmental fallow. For all AES measures, both obligatory and voluntary, the farmer is entitled to monetary compensation ( $€$ per hectare) based on generally agreed support levels. The current extent of implementation of these measures (in hectares) was obtained from Finnish agricultural statistics.

The relative effectiveness of these AES measures for enhancing butterfly diversity was assessed using the results from previous Finnish case studies. These data and the valuation process are described in more detail in SM, section S4. In this approach, the actual species richness estimates for each AES measure were replaced with relative estimates. This facilitated quantitative comparison and ranking of individual AES measures according to their significance for butterflies (Fig. 4).

The results revealed that the voluntary special measure for the management of traditional biotopes, usually grazing, is by far the most efficient AES measure promoting suitable habitats for grassland butterflies that are currently 


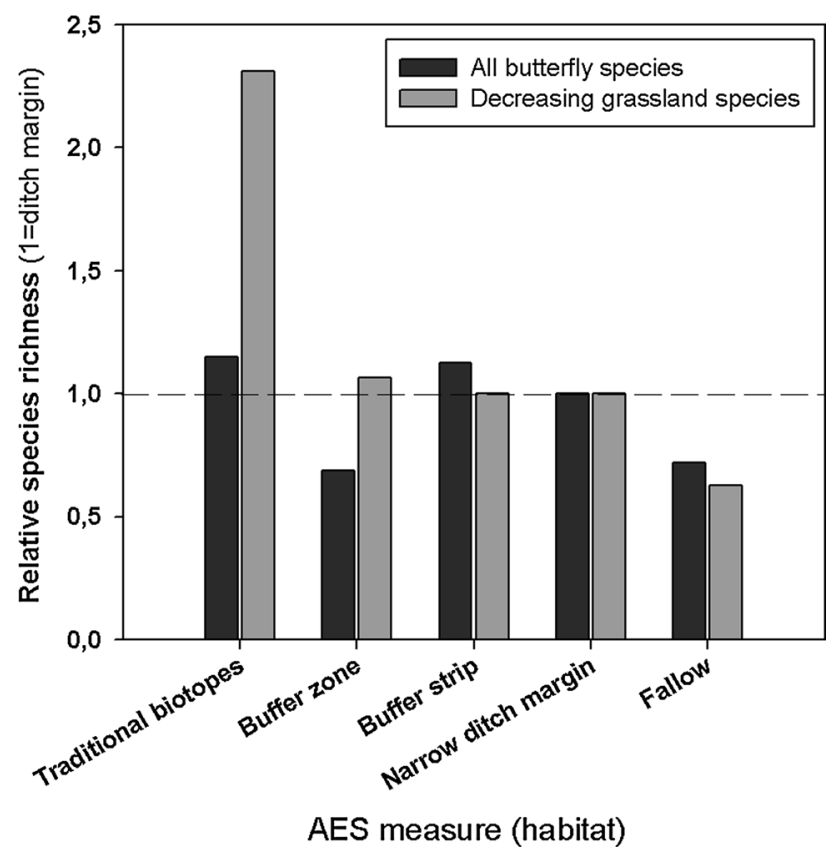

Fig. 4 Relative species richness of butterflies for different AES measures. The actual species richness values were rescaled to the reference level of ordinary ditch margins (assigned a value of one)

in decline (Fig. 4). All other AES measures were of relatively low value for grassland butterflies.

The total areas of agricultural land under each AES option are currently rather low (Table 1 ). This hampers their significance for overall species conservation and adaptation. A national target level for the management of traditional biotopes has been set at 60,000 ha (Salminen and Kekäläinen 2000), but there is still some way to go to achieve this goal, as the area under AES contracts has remained rather stable over the past decade.

Most of the measures in the Finnish AES are targeted primarily to reduce nutrient run-off from arable areas (Grönroos et al. 2007; Aakkula et al. 2012). These measures are typically applied on species-poor habitats of little or no value for butterflies. It is therefore evident that the Finnish AES is not optimally designed for benefiting grassland butterflies. Additional work on targeted new AES options for enhancing biodiversity is therefore considered a priority.

\section{Dispersal corridors}

Dispersal corridors-also known as ecological corridors (Öckinger and Smith 2008) or movement corridors (Simberloff et al. 1992) —offer an explicit option for enhancing species adaptation to climate change (Huntley et al. 2006; Heller and Zavaleta 2009) and have been highlighted in European adaptation policy (CEC 2009). These are designed to enhance species' range expansion to new, currently unoccupied areas by linking present-day populations to alternative locations that are projected to become climatically suitable in the future.

The analysis of the potential effectiveness of dispersal corridors for grassland butterflies under future climate change is laborious. Thus, the analysis here focused on one example species, the Hesperia comma butterfly, which provides a useful indicator for valuable grasslands. This species was also used in a subsequent analysis of translocation.

Table 1 Spatial information for the six potential dispersal corridors constructed for the Hesperia comma butterfly

\begin{tabular}{|c|c|c|c|c|c|c|}
\hline Corridor & 1 & 2 & 3 & 4 & 5 & 6 \\
\hline Climate change scenario & 2LLL & 1MMH & 4HMM & 2LLL & $1 \mathrm{MMH}$ & 4HMM \\
\hline Modelling method & GAM & GAM & GAM & GLM & GLM & GLM \\
\hline No. 2-km grid cells & 55 & 35 & 59 & 187 & 84 & 132 \\
\hline \multicolumn{7}{|l|}{ AES managed and other valuable open grassland } \\
\hline Mean cover (ha) & 4.0 & 5.5 & 2.5 & 1.4 & 3.3 & 1.3 \\
\hline No. of cells $<2.5 \%$ (10 ha) & 50 & 29 & 55 & 179 & 77 & 128 \\
\hline Area needed to reach $2.5 \%$ (ha) & 398 & 266 & 493 & 1,687 & 671 & 1,198 \\
\hline Establishment and management costs $(1,000 € /$ year/total area $)$ & 186 & 124 & 231 & 791 & 314 & 561 \\
\hline \multicolumn{7}{|l|}{ All open and wooded grasslands } \\
\hline Mean cover (ha) & 7.0 & 2.0 & 4.8 & 3.3 & 6.2 & 3.3 \\
\hline No. of cells $<2.5 \%$ (10 ha) & 44 & 24 & 51 & 171 & 72 & 123 \\
\hline Area needed to reach $2.5 \%$ (ha) & 318 & 186 & 428 & 1,434 & 541 & 1,014 \\
\hline Establishment and management costs $(1,000 € /$ year/total area $)$ & 149 & 87 & 200 & 672 & 253 & 475 \\
\hline
\end{tabular}

The two modelling methods are GAM (generalized additive models) and GLM (generalized linear models), and the three climate change scenarios: 2LLL, 1MMH and 4HMM (cf. Table S1.2, SM). Also shown are the estimated costs of establishing the corridors (applicable over a 20-year period) 
The GIS analysis first identified six $10-\mathrm{km}$ grid cells containing grassland habitats and projected to be climatically very suitable under future climate in 2051-2080 by the BEMs developed for Hesperia comma (see Fig. 3 above). The six target 10-km grid cells were selected based on model outputs for combinations of three climate change scenarios and two modelling methods (Fig. 5). They were used both as tentative destination points in the corridor constructions and as target areas for species translocation. For characteristics of the corridor target cells, see SM, section S5.1.

A GIS environment was used to construct six example corridors between one of the $10-\mathrm{km}$ grid cells with current known records of Hesperia comma, and each of the six $10-\mathrm{km}$ grid cells deemed climatically very suitable

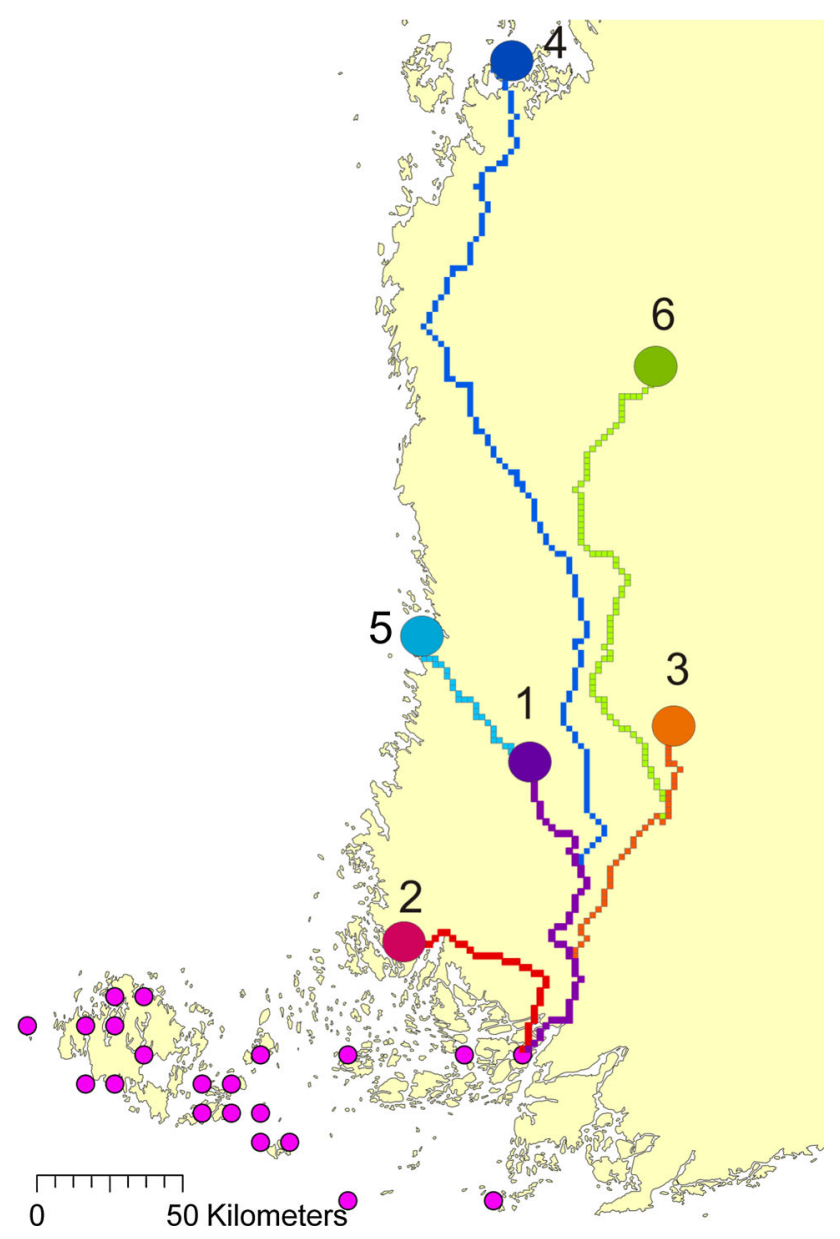

Fig. 5 Hypothetical stepping-stone corridors based on adjacent 2-km grid cells between one of the existing areas for Hesperia comma and six projected areas of high future climatic suitability based on bioclimatic envelope models with two types of modelling methods (GAM and GLM) and three different climate change scenarios for 2051-2080: (1) Purple GAM/2LLL; (2) red GAM/1MMH; (3) orange GAM/4HMM; (4) dark blue GLM/2LLL; (5) light blue GLM/ 1MMH; and (6) green GLM/4HMM. Pink dots in south-west Finland indicate $10-\mathrm{km}$ cells with known records of the species in 1991-2000 under the 2051-2080 climate conditions. The corridor building was done by manually constructing a pathway made of $2 \mathrm{~km}$ grid cells linking the present-day occurrence area and each of the target areas (for details, see SM, section S5.2).

Interestingly, the six example corridors varied considerably with respect to their length and the spatial location of the target area (Fig. 5), suggesting that conservation planning for dispersal corridors based on BEMs may be strongly affected by the methodological choices made in the process. In a clear majority of the six corridors, the present-day grassland habitat cover along the corridor is less than the target level of $2.5 \%$, or 10 ha in a $2-\mathrm{km}$ cell (Table 1). This suggests that very large additional adaptation efforts, such as land cover conversion or AES-based restoration, would be needed to ensure the effectiveness of these dispersal corridors, which implies high costs (see below).

These six example corridors are only a very small selection of the hundreds of potential dispersal corridors. Nevertheless, these examples illustrate that there are considerable uncertainties in selecting suitable corridors attributable to the different climate change scenarios and BEM modelling methods applied. Without doubt, differences in the suitability of corridor pathways would also emerge between different species. Thus, increasing the number of hypothetical corridors to cover more examples for one species and also to cover other species would increase the robustness of the estimates. However, given the low present-day levels of suitable habitats, it is also apparent that additional AES would be needed along tens or even hundreds of kilometres to ensure that these could function effectively as dispersal corridors for grassland species.

\section{Species translocations}

The final major option considered is the translocation of species (also referred to as assisted colonization or assisted migration). This option is increasingly advocated as a potentially useful measure to reduce the harmful impacts of climate change on species populations (Hoegh-Guldberg et al. 2008; Thomas 2011). However, the success of species translocation to date has been variable and also somewhat controversial (Ricciardi and Simberloff 2009; Lawler and Olden 2011). Nonetheless, one recent UK study employing a wealth of empirical data shows that assisted colonization could be a useful and cost-effective means to assist butterfly species in tracking climatic shifts more effectively (Willis et al. 2009). In this study, the economic potential for translocation was investigated with a detailed analysis of Hesperia comma, using the identified six example target end points analysed above. 


\section{Economic analysis of adaptation options}

The preceding analysis provides valuable information on potential options. However, these need to be complemented with other criteria, notably in relation to the costs of the measures, to help prioritize (or rank) the options. CEA is the tool applied in this study ("Step 3: costeffectiveness of adaptation options" section, above).

CEA is first applied to the AES options. Cost information on the establishment and management of different AES measures was collected from a stakeholder workshop in 2011, a farmer survey 2012 and interviews with key farmers. This was supplemented with data and the literature on AES measures and costs. A summary of the costs and the overall present value costs are presented in Table 2 . The overall present value costs are the costs discounted over the time period of the AES agreement, which is a 3-year lifetime for most measures (see Table S6, SM for more detail).

Costs are uncertain because different farms have varying unit costs, depending on a number of context-specific factors, including topography and scale at which the scheme is applied. For example, a survey of nine traditional biotope AESs shows a range of annual establishment costs of $€ 55 / \mathrm{ha}-€ 1,214 / \mathrm{ha}$ and a range of annual management costs of $€ 174 /$ ha $-€ 1,083 /$ ha. In order to provide an initial indication of this cost uncertainty, ranges are adopted that

Table 2 Mean costs of establishing and managing AES measures and the cost-effectiveness of AES measures

\begin{tabular}{lclr}
\hline$€ /$ Tha & Total costs (3-year contract) & $\begin{array}{l}\text { Cost- } \\
\text { effectiveness of } \\
\text { measure } € \\
\text { 2,012) }\end{array}$ \\
\hline Environmental fallow & & & \\
Resource cost & $488(137-1,377)$ & Low & 285 \\
Opportunity cost & $282(79-796)$ & Medium & 1,014 \\
Total annual cost & $770(217-2,173)$ & High & 2,861 \\
PVC & $710(200-2,003)$ & & \\
Buffer zone & & & \\
Resource cost & $729(205-2,057)$ & Low & 241 \\
Opportunity cost & $291(82-821)$ & Medium & 858 \\
Total annual cost & $1,020(287-2,878)$ & High & 2,420 \\
PVC & $944(265-2,663)$ & & \\
Traditional biotope & & Low & 308 \\
Resource cost & $2,442(687-6,891)$ & Medium & 1,096 \\
Opportunity cost & $282(79-796)$ & High & 3,092 \\
Total annual cost & $2,724(766-7,687)$ & & \\
PVC & $2,520(709-7,110)$ & & \\
\hline
\end{tabular}

$\mathrm{PVC}$ is total present value costs (see SM, section S6, equation S5). Bracketed ranges are explained in the text (discount rate: Year 1: 0.962, Year 2: 0.925 and Year 3: 0.889) reflect the variance around the mean in this small survey of traditional biotope AES costs. Thus, low and high cost estimates are shown in Table 2, along with medium estimates. It should be noted that this analysis is undertaken from the perspective of maximizing social welfare (i.e. the net economic benefits that accrue to both consumers and producers). It does not include the effects of subsidies that have an influence on farmers' decisions regarding AES uptake, because subsidies simply represent a transfer of resources between parties and have no effect on total net economic benefits (see Mishan and Quah 2007).

The cost-effectiveness is next derived by combining these estimates with the earlier analysis of relative species richness (Table 2). The table shows, under each part of the cost range, that all three options are fairly similar in terms of their cost-effectiveness at the order of magnitude level. The use of CEA demonstrates that the ranking changes from that which would result from reliance on costs or effectiveness on their own: the environmental fallow option has the lowest cost per hectare, but the higher species richness of buffer zones more than compensates for their higher costs and they are therefore slightly more costeffective within a given part of the unit cost range. Conversely, while the traditional biotope has the highest species richness of the three, its relatively high cost indicates it is slightly less cost-effective.

However, Table 2 also shows that comparison across different parts of the cost range can yield multiple rankings. Thus, if traditional biotopes are found to have unit costs at the low end of their range, while the buffer zone has unit costs at the high end of its range, then traditional biotopes might be more cost-effective. The instability in the rankings is likely to be further exacerbated if the uncertainties in the measures of effectiveness are included in the analysis. This highlights how CEA results are not likely to be easily transferable; ranking is more reliable when the precise context is defined, and data collected accordingly. It should also be recalled that AESs are not primarily designed for butterfly conservation, and a broader view of the multiple environmental benefits of these measures is needed when considering their current application-and potentially their ranking for future adaptation options.

The principle of applying the concept of CEA to dispersal corridors is illustrated by building on the analysis in the "Dispersal corridors" section for Hesperia comma. In this case, the costs are associated with the additional interventions needed to achieve the target levels for corridor connectivity, i.e. to achieve the target habitat level of $2.5 \%$ for each of the six indicative corridors, shown in Table 1. This is achieved through the introduction of AES contracts and non-productive investment subsidies for forest habitats to convert cultivated fields and forested land 
Table 3 Required actions and related costs of species translocation to six target locations (cf. Fig. 5)

a At least 3 years of monitoring are typically required to establish the success (or otherwise) of translocation

\begin{tabular}{lllllll}
\hline Target location & 1 & 2 & 3 & 4 & 5 & 6 \\
\hline Climate change scenario & 2LLL & 1MMH & 4HMM & 2LLL & 1MMH & 4HMM \\
Modelling method & GAM & GAM & GAM & GLM & GLM & GLM \\
& Costs $(€)$ & & & & \\
Preparatory actions & 3,050 & 3,010 & 3,200 & 3,650 & 3,280 & 3,445 \\
Translocation & 1,205 & 1,190 & 1,260 & 1,575 & 1,390 & 1,470 \\
Supplementing translocation and monitoring & 1,205 & 1,190 & 1,260 & 1,575 & 1,390 & 1,470 \\
Further monitoring for two years & 2,765 & 2,740 & 2,865 & 3,400 & 3,030 & 3,195 \\
Total cost $(€)$ & 8,225 & 8,130 & 8,585 & 10,200 & 9,090 & 9,580 \\
\hline
\end{tabular}

on a half-and-half basis, so that $2.5 \%$ of the cover of the 2-km corridor cells would become suitable habitat for grassland butterflies. In this exercise, it was assumed that the converted habitat patches throughout the corridors would be managed based on AES contracts or non-productive investment subsidies for at least 20 years. Such a time period is generally required for converted cultivated field and forest sites to develop into suitable habitats for grassland butterflies. Here, of the six corridors evaluated, Corridor 2 appears to be most cost-effective based on the establishment and management costs.

Here, it should be noted that the costs of conserving this one butterfly species are estimated separately for one climate scenario/model combination. A more robust adaptation strategy, that considered uncertainty, would possibly need multiple corridors, to connect to a portfolio of target climatically suitable locations.

Finally, cost-effectiveness of the translocation option has been analysed, again building on the results for Hesperia comma. The estimated costs ranged from $€ 5,400$ to $€ 6,800$ per intervention, with some variation between the six target locations identified from the model outputs from GAM, GLM and the three climate scenarios (Table 3) due to differences in travel costs. The total costs of translocation were a fraction of the costs of stepping-stone corridor construction (cf. Tables 1, 3). However, these costs may not fully capture the activities needed for successful translocation of grassland butterflies, such as potential need for selective cutting of trees or rotational (e.g. five yearly) clearance of bushes from the translocation target site, which cautions against the direct comparison of the options. Furthermore, these costs only relate to the translocation of one species, while the dispersal corridors potentially offer dispersal routes for multiple species and also provide wider environmental benefits. Translocation of multiple species, possibly even all key species elements of a given grassland ecosystem, might also be considered, though cost comparisons with constructing dispersal corridors could become quite complicated. This is because the costs of transferring multiple species are not directly additive-there can be differences between species in translocation costs for a given target location, depending on the future suitability and species' ecology at the location. Moreover, the success rate of translocations varies from case to case and is often low due to variation in site-specific habitats. Overall, there is a need for a portfolio of translocation sites to take account of climate and model uncertainties in the selection of suitable future climatic locations.

\section{Step 4: farmer survey}

Out of the 385 respondents who answered the farmer survey, $54 \%$ stated that the current state of grassland biodiversity conservation was adequate, while a third thought that conservation should be increased. One-tenth of the farmers responded that too much effort had already gone into biodiversity conservation, but three quarters of farmers viewed the AES measures as an effective way to protect biodiversity and increase recreational opportunities, while less than $10 \%$ disagreed with this view. A large majority of respondents also considered beautiful scenery and the strengthening of emotional ties to farmland nature to be important to them.

Finally, the farmers were asked which of the available biodiversity conservation AES measures they would be willing to implement at their farm. Their preferences, in descending order, were the establishment and management of environmental fallows (68\% indicated a willingness to implement), buffer zones (57\%) and traditional biotopes (42\%). Forty-two per cent would also be willing to manage other biodiversity habitats and $35 \%$ wetlands. The relative willingness of farmers may reflect a strategic interest in these measures or may simply reflect which are the easiest to implement, require less work than other measures or are most profitable, i.e. where the subsidy is large in comparison to the realized costs.

\section{Conclusions}

This paper has examined the potential impact of climate change on grassland biodiversity, using butterflies as a 
representative indicator species. It also investigated options to enhance the adaptation of grassland biodiversity in Finland under a changing climate: short-term options based on a CEA of current agri-environmental scheme measures, and longer-term options in the form of dispersal corridors and translocation.

The results lead to a number of important conclusions. First, in relation to the analysis of bioclimatic envelopes and modelling of potential impacts on butterfly species, the task of considering multiple butterfly species and of examining uncertainties related to future climate and to methods of impact modelling has proven to be both challenging and time-consuming. However, it is important to consider these uncertainties, as the results reveal major differences in the future areas that are forecasted to be climatically suitable (cf. Lawler et al. 2006; Pearson et al. 2006). This cautions against the narrow use of single or averaged climate projections or single modelling approaches when planning ecosystem adaptation, especially in light of known limitations in data and modelling techniques.

The detailed impact assessment of future climatically suitable sites and possible dispersal corridors (for Hesperia comma) has revealed considerable spatial gaps between the current and projected suitable areas for most grassland butterflies in Finland. The results also indicate that the current extent of semi-natural grasslands is generally far too low to provide a secure passage from current to future suitable areas for the selected butterfly species. This implies a potential need to increase the amount of seminatural (grazed or mowed) managed grasslands in Finland.

Second, with regard to the analysis of current AES measures, it was found that while the individual options of environmental fallow, buffer zones and traditional biotope had very different levels of "ecological" or "species conservational" effectiveness, in broad terms, they all had similar cost-effectiveness as an adaptation option. This result points to the need, when selecting and prioritizing adaptation options, to move beyond an analysis of effectiveness alone and to factor cost-efficiency into the analysis, in order to ensure the best use of resources and to minimize the costs of achieving adaptation objectives.

Third, in relation to the additional adaptation options for addressing longer-term climatic shifts, it was found that the low levels of current suitable habitats for grassland butterfly species act as a major barrier to the establishment of dispersal corridors. As a result, the areas of additional habitat or number of schemes needed to provide habitat stepping stones along these corridors are relatively high, which is subsequently reflected in the conservation costs. The alternative of species translocations appeared to be a lower cost option. However, its application is also limited by the general difficulty of finding sufficiently large and good quality recipient sites as well as by insufficient knowledge of species' exact habitat requirements. This is reflected in existing field studies: the previous species translocations undertaken in Finland have had varied success (Kuussaari, M. and Pöyry, J., personal communication).

Furthermore, a critical issue with both these additional options is the uncertainty across different climate simulations and impact models, as this indicates a broad range of site suitability in endpoint target areas, whether these pertain to dispersal corridors or translocation actions. A consideration of this uncertainty indicates it would be unwise to narrowly focus plans for these options on the results of a single climate simulation or BEM model; instead, it would seem preferable to plan a portfolio of sites or corridors that could be effective over the range of possible projected futures and outcomes. However, this has resource implications. It suggests that a more sensible option would be to move towards an iterative adaptive management framework that includes monitoring, learning and changing management strategies as the evidence emerges.

Finally, the survey results indicate a relatively high willingness among farmers to adopt AES measures that could be beneficial for grassland biodiversity. However, this finding contrasts with the relatively low levels of uptake of these measures, and current levels are insufficient to provide sufficient resilience against future climate change. Increasing the uptake of biodiversity-related AES measures by farmers, especially for those options which appear cost-effective, is seen as a relatively early and effective form of adaptation, but the socio-institutional analysis and survey results indicate this will prove difficult without additional planned intervention, either in the form of information and awareness raising or through changes in the incentive structure to encourage these measures.

Acknowledgments The funding for this work was provided by the European Community's Seventh Framework Programme, as part of the MEDIATION (Methodology for Effective Decision-making on Impacts and AdaptaTION) project with supplementary funds from the Academy of Finland project A-LA-CARTE (Assessing limits of adaptation to climate change and opportunities for resilience to be enhanced). Josef Settele and Oliver Schweiger kindly provided the European Butterfly Atlas data for use in this study. We are very grateful to two anonymous reviewers for their valuable comments.

Open Access This article is distributed under the terms of the Creative Commons Attribution License which permits any use, distribution, and reproduction in any medium, provided the original author(s) and the source are credited.

\section{References}

Aakkula J, Kuussaari M, Rankinen K, Ekholm P, Heliölä J, Hyvönen T, Kitti L, Salo T (2012) Follow-up study on the impacts of agrienvironmental measures in Finland. In: OECD (ed) Evaluation 
of agri-environmental policies: selected methodological issues and case studies. OECD Publishing, Organisation for Economic Co-operation and Development, Paris, pp 111-128

Allouche O, Tsoar A, Kadmon R (2006) Assessing the accuracy of species distribution models: prevalence, kappa and the true skill statistic (TSS). J Appl Ecol 43:1223-1232

Araújo MB, Peterson AT (2012) Uses and misuses of bioclimatic envelope modeling. Ecology 93:1527-1539

Arponen A, Heikkinen RK, Paloniemi R, Pöyry J, Similä J, Kuussaari $M$ (2013) Improving conservation planning of semi-natural grasslands: integrating connectivity into agri-environment schemes. Biol Conserv 160:234-241

Bastian O (2013) The role of biodiversity in supporting ecosystem services in Natura 2000 sites. Ecol Indic 24:12-22. doi:10.1016/ j.ecolind.2012.05.016

Braschler B, Hill JK (2007) Role of larval host plants in the climatedriven range expansion of the butterfly Polygonia c-album. J Anim Ecol 76(3):415-423

CEC (2009) White paper: adapting to climate change: towards a European framework for action. Commission of the European Communities, COM(2009) 147/4. Brussels

Fielding A, Bell J (1997) A review of methods for the assessment of prediction errors in conservation presence/absence models. Environ Conserv 24:38-49

Franco AMA, Hill JK, Kitschke C, Collingham YC, Roy DB, Fox R, Huntley B, Thomas CD (2006) Impacts of climate warming and habitat loss on extinctions at species' low-latitude range boundaries. Glob Change Biol 12:1545-1553. doi:10.1111/j. 1365-2486.2006.01180.x

Grönroos J, Hietala-Koivu R, Kuussaari M, Laitinen P, Lankoski J, Lemola R, Miettinen A, Perälä P, Puustinen M, Schulman A, Salo T, Siimes K, Turtola E (2007) Analyysi maatalouden ympäristötukijärjestelmästä 2000-2006 (Analysis of the Finnish agri-environmental programme 2000-2006). The Finnish Environment 19/2007 (in Finnish with English abstract)

Hannah L, Midgley G, Andelman S, Araujo M, Hughes G, MartinezMeyer E, Pearson R, Williams P (2007) Protected area needs in a changing climate. Front Ecol Environ 5:131-138. http://dx.doi. org/10.1890/1540-9295(2007)5[131:PANIAC]2.0.CO;2

Heikkinen RK, Luoto M, Araújo MB, Virkkala R, Thuiller W, Sykes MT (2006) Methods and uncertainties in bioclimatic envelope modelling under climate change. Progr Phys Geogr 30:751-777

Heikkinen RK, Luoto M, Leikola N, Poyry J, Settele J, Kudrna O, Marmion M, Fronzek S, Thuiller W (2010) Assessing the vulnerability of European butterflies to climate change using multiple criteria. Biodiv Conserv 19:695-723. doi:10.1007/ s10531-009-9728-x

Heikkinen RK, Marmion M, Luoto M (2012) Does the interpolation accuracy of species distribution models come at the expense of transferability? Ecography 35:276-288. doi:10.1111/j.16000587.2011.06999.x

Heller NE, Zavaleta ES (2009) Biodiversity management in the face of climate change: a review of 22 years of recommendations. Biol Conserv 142:14-32. doi:10.1016/j.biocon.2008.10.006

Hill JK, Thomas CD, Huntley B (2003) Modeling present and potential future ranges of European butterflies using climate response surfaces. In: Bogs C, Watt W, Ehrlich P (eds) Butterflies. Ecology and evolution taking flight. The University of Chicago Press, Chicago, pp 149-167

Hinkel J, Bisaro A (eds) (2014) Methodological choices in problemoriented adaptation research. Reg Environ Change (submitted)

Hoegh-Guldberg $\mathrm{O}$, Hughes L, McIntyre S, Lindenmayer DB, Parmesan C, Possingham HP, Thomas CD (2008) Assisted colonization and rapid climate change. Science 321:345-346. doi:10.1126/science.1157897
Huntley B, Collingham YC, Green RE, Hilton GM, Rahbek C, Willis SG (2006) Potential impacts of climatic change upon geographical distributions of birds. Ibis 148:8-28. doi:10.1111/j.1474919X.2006.00523.X

Huntley B, Barnard P, Altwegg R, Chambers L, Coetzee BWT, Gibson L, Hockey PAR, Hole DG, Midgley GF, Underhill LG, Willis SG (2010) Beyond bioclimatic envelopes: dynamic species' range and abundance modelling in the context of climatic change. Ecography, 621-626. doi:10.1111/j.1600-0587.2009.06023.x

Kemppainen R, Lehtomaa L (2009) Perinnebiotooppien hoidon tila ja tavoitteet (The status and goals of managing valuable rural habitats in Finland). Lounais-Suomen ympäristökeskuksen raportteja (Reports of the Lounais-Suomi Regional Environmental Center 2/2009). Lounais-Suomi Regional Environmental Center, Turku (in Finnish with English abstract)

Kivinen S, Luoto M, Heikkinen RK, Saarinen K, Ryttari T (2008) Threat spots and environmental determinants of red-listed plant, butterfly and bird species in boreal agricultural environments. Biodiv Conserv 17:3289-3305

Kleijn D, Rundlof M, Scheper J, Smith HG, Tscharntke T (2011) Does conservation on farmland contribute to halting the biodiversity decline? Trends Ecol Evol 26:474-481. doi:10. 1016/j.tree.2011.05.009

Kuussaari M, Heliola J, Luoto M, Poyry J (2007) Determinants of local species richness of diurnal Lepidoptera in boreal agricultural landscapes. Agric Ecosyst Environ 122:366-376

Lawler JJ, Olden JD (2011) Reframing the debate over assisted colonization. Front Ecol Environ 9:569-574. doi:10.1890/ 100106

Lawler JJ, White D, Neilson RP, Blaustein AR (2006) Predicting climate-induced range shifts: model differences and model reliability. Glob Change Biol 12:1-17

Loarie SR, Duffy PB, Hamilton H, Asner GP, Field CB, Ackerly DD (2009) The velocity of climate change. Nature 462:1052-1055. doi:10.1038/nature08649

MAF (2007) Rural Development Programme for Mainland Finland 2007-2013. CCI 2007 FI 06 RPO 001. Finland's Ministry of Agriculture and Forestry

Menéndez R (2007) How are insects responding to global warming? Tijdschr Entom 150:355-365

Mishan EJ, Quah E (2007) Cost-benefit analysis, 5th edn. Routledge, London

Öckinger E, Smith HG (2008) Do corridors promote dispersal in grassland butterflies and other insects? Landsc Ecol 23:27-40

Öckinger E, Eriksson AK, Smith HG (2006) Effects of grassland abandonment, restoration and management on butterflies and vascular plants. Biol Conserv 133:291-300

Pearce D, Atkinson G, Mourato S (2006) Cost-benefit analysis and the environment: recent developments. OECD Publishing, Paris

Pearson RG, Thuiller W, Araújo MB, Martinez-Meyer E, Brotons L, McClean C, Miles L, Segurado P, Dawson TE, Lees DC (2006) Model-based uncertainty in species' range prediction. J Biogeogr 33:1704-1711

Peterson AT, Martínez-Meyer E, González-Salazar C, Hall PW (2004) Modeled climate change effects on distributions of Canadian butterfly species. Can J Zool 82:851-858

Polus E, Vandewoestijne S, Choutt J, Baguette M (2007) Tracking the effects of one century of habitat loss and fragmentation on calcareous grassland butterfly communities. Biodiv Conserv 16:3423-3436. doi:10.1007/s10531-006-9008-y

Pöyry J, Luoto M, Heikkinen RK, Kuussaari M, Saarinen K (2009) Species traits explain recent range shifts of Finnish butterflies. Glob Change Biol 15:723-743

Pykälä J (2000) Mitigating human effects on European biodiversity through traditional animal husbandry. Conserv Biol 14:705-712 
Pyykkönen P, Lehtonen H, Koivisto A (2010) Maatalouden rakennekehitys ja investointitarve vuoteen 2020 (Structural change and investments in Finnish agriculture 2010-2020). PTT työpapereita 125/PTT Working Papers 125 (in Finnish with English abstract)

Ricciardi A, Simberloff D (2009) Assisted colonization is not a viable conservation strategy. Trends Ecol Evolut 24:248-253. doi:10. 1016/j.tree.2008.12.006

Salminen P, Kekäläinen H (2000) Perinnebiotooppien hoito Suomessa. Perinnemaisemien hoitotyöryhmän mietintö. (The management of agricultural heritage habitats in Finland. Report by the Heritage Landscapes Working Group). The Finnish Environment 443. Finnish Environment Institute, Helsinki (in Finnish with English abstract)

Schulman A, Heliölä J, Pykälä J (2006) Maatalouden ympäristötuen sopimusalueiden laatu ja hoidon toteutuminen: Perinnebiotooppien hoidon ja luonnon monimuotoisuuden edistämisen erityistuet (Quality and management of contract areas of the agri-environmental support-the special support for management of traditional rural biotopes and for enhancement of biodiversity). The Finnish Environment 3/2006. Finnish Environment Institute, Helsinki (in Finnish with English abstract)

Schweiger O, Heikkinen RK, Harpke A, Hickler T, Klotz S, Kudrna O, Kuhn I, Poyry J, Settele J (2012) Increasing range mismatching of interacting species under global change is related to their ecological characteristics. Glob Ecol Biogeogr 21:88-99. doi:10.1111/j.1466-8238.2010.00607.x

Settele J, Kühn E (2009) Insect conservation. Science 325:41-42. doi:10.1126/science. 1176892

Simberloff D, Farr JA, Cox J, Mehlman DW (1992) Movement corridors: conservation bargains or poor investment? Conserv Biol 1:63-71

Strijker D (2005) Marginal lands in Europe-causes of decline. Basic Appl Ecol 6:99-106. doi:10.1016/j.baae.2005.01.001

Thomas CD (2011) Translocation of species, climate change, and the end of trying to recreate past ecological communities. Trends Ecol Evolut 26:216-221. doi:10.1016/j.tree.2011.02.006

Thuiller W, Lafourcade B, Engler R, Araujo MB (2009) BIOMOD—a platform for ensemble forecasting of species distributions. Ecography 32:369-373. doi:10.1111/j.1600-0587.2008.05742.x

Tietjen B, Cramer W, Bottcher H, Kindermann G, Fuss S, Obersteiner M, Hunt A, Watkiss P (2011) WP 2F: ecosystems and forests. Global report analysis. Final Report to Sponsor, Deliverable 2F3, Full Costs of Climate Change. http://webarchive.iiasa.ac.at/ Admin/PUB/Documents/XO-11-060.pdf
TIKE (2011) Yearbook of farm statistics. Information Centre of the Ministry of Agriculture and Forestry (TIKE) of Finland. Helsinki, 2011. Edita Publishing

Vainio M, Kekäläinen H, Alanen A, Pykälä J (2001) Suomen perinnebiotoopit. Perinnemaisemaprojektin valtakunnallinen loppuraportti (Traditional rural biotopes in Finland. Final report of the nationwide inventory). The Finnish Environment 527. Finnish Environment Institute, Helsinki

van Berkel DB, Verburg PH (in press) Spatial quantification and valuation of cultural ecosystem services in an agricultural landscape. Ecol Ind. doi:10.1016/j.ecolind.2012.06.025

Van Swaay CAM, Van Strien AJ, Harpke A, Fontaine B, Stefanescu C, Roy D, Maes D, Kühn E, Õunap E, Regan E, Švitra G, Heliölä J, Settele J, Warren MS, Plattner M, Kuussaari M, Cornish N, Garcia Pereira P, Leopold P, Feldmann R, Jullard R, Verovnik R, Popov S, Brereton T, Gmelig Meyling A, Collins S (2010) The European Butterfly Indicator for Grassland species 1990-2009. Report VS2010.010. De Vlinderstichting, Wageningen

Virkkala R, Heikkinen RK, Leikola N, Luoto M (2008) Projected large-scale range reductions of northern-boreal land bird species due to climate change. Biol Conserv 141:1343-1353

Wallisdevries MF, Van Swaay CAM (2006) Global warming and excess nitrogen may induce butterfly decline by microclimatic cooling. Glob Change Biol 12:1620-1626. doi:10.1111/j.13652486.2006.01202.x

Warren MS, Hill JK, Thomas JA, Asher J, Fox R, Huntley B, Roy DB, Telfer MG, Jeffcoate S, Harding P, Jeffcoate G, Willis SG, Greatorex-Davies JN, Moss D, Thomas CD (2001) Rapid responses of British butterflies to opposing forces of climate and habitat change. Nature 414:65-69

Watkiss P, Hunt A (2012) Cost-effectiveness analysis: decision support methods for adaptation, MEDIATION Project, Briefing Note 2. Funded by the EC's 7FW

Wenzel M, Schmitt T, Weitzel M, Seitz A (2006) The severe decline of butterflies on western German calcareous grasslands during the last 30 years: a conservation problem. Biol Conserv 128:542-552

Willis SG, Hill JK, Thomas CD, Roy DB, Fox R, Blakeley DS, Huntley B (2009) Assisted colonization in a changing climate: a test-study using two UK butterflies. Conserv Lett 2:45-51. doi:10.1111/j.1755-263X.2008.00043.x

Zhu X, van Ierland E (2010) Report on review of available methods for cost assessment. Deliverable 3.1 from the MEDIATION Project 